\title{
Static and Dynamic Mechanical Properties of Long-Span Cable-Stayed Bridges Using CFRP Cables
}

\author{
Mei Kuihua, Sun Shengjiang, Jin Guoqing, and Sun Yamin \\ School of Highway, Chang'an University, Xian 710064, China \\ Correspondence should be addressed to Mei Kuihua; meikuihua@chd.edu.cn \\ Received 17 April 2017; Revised 23 July 2017; Accepted 2 August 2017; Published 7 September 2017 \\ Academic Editor: Gianmarco de Felice \\ Copyright (c) 2017 Mei Kuihua et al. This is an open access article distributed under the Creative Commons Attribution License, \\ which permits unrestricted use, distribution, and reproduction in any medium, provided the original work is properly cited.

\begin{abstract}
The elastic modulus and deadweight of carbon fiber-reinforced polymer (CFRP) cables are different from those of steel cables. Thus, the static and dynamic behaviors of cable-stayed bridges using CFRP cables are different from those of cable-stayed bridges using steel cables. The static and dynamic performances of the two kinds of bridges with a span of $1000 \mathrm{~m}$ were studied using the numerical method. The effects of geometric nonlinear factors on static performance of the two kinds of cable-stayed bridges were analyzed. The live load effects and temperature effects of the two cable-stayed bridges were also analyzed. The influences of design parameters, including different structural systems, the numbers of auxiliary piers, and the space arrangement types of cable, on the dynamic performance of the cable-stayed bridge using CFRP cables were also studied. Results demonstrate that sag effect of the CFRP cable is much smaller than that of steel cable. The temperature effects of CFRP cable-stayed bridge are less than those of steel cable-stayed bridge. The vertical bending natural vibration frequency of the CFRP cable-stayed bridge is generally lower than that of steel cable-stayed bridge, whereas the torsional natural vibration frequency of the former is higher than that of the latter.
\end{abstract}

\section{Introduction}

Given their large spanning ability, elegant appearance, and good aerodynamic stability, cable-stayed bridges have experienced a prosperous development in the last 30 years and are still regarded as the first choice to cross rivers, valleys, and even straits. However, traditional steel cables are prone to corrosion and fatigue, which would cause premature failure of the cable. In addition, the substantial weight of steel cables results in a pronounced sag effect, thereby decreasing the effective stiffness of the cable in a superspan cablestayed bridge. Carbon fiber-reinforced polymers (CFRP) possess many advantages, including light weight, high tensile strength, and excellent corrosion and fatigue resistance. These properties of CFRP make them very attractive in superspan cable-stayed bridges. In fact, as early as 1987, U. Meier and H. Meier (e.g., [1-3]) evaluated the feasibility of building a CFRP cable-stayed bridge. Hence, a few cable-stayed bridges using CFRP cables have been built for research purposes (e.g., [4-8]). The first cable-stayed bridge using CFRP cables constructed in China was the Xishan Pedestrian Bridge at Jiangsu University, which was designed and studied by Southeast University [9].

At present, a few scholars have studied the static and dynamic performances, as well as wind and seismic performances, of cable-stayed bridges using CFRP cables. Khalifa et al. [10] proposed the analysis and design aspects of an FRP cable-stayed bridge by describing the steps taken in the design of the first US FRP cable-stayed pedestrian bridge constructed in Lincoln. The overall behaviors of the whole bridge under static and dynamic loads were analyzed using three-dimensional macro models. Adanur and Gunaydin [11, 12] presented a numerical study on the stochastic seismic analysis of a cable-stayed bridge subjected to earthquake ground motion using CFRP cables from the prototype of Jindo Bridge. Cheng and Lau [13] studied the dynamic behavior of CFRP cable-stayed bridges by substituting CFRP cables for conventional steel cables in Nanpu Bridge. In their study, results showed that the use of CFRP cables had a stiffening effect on the bridge system. Mei and $\mathrm{Lu}[14]$ and Xie et al. [15] studied the static and dynamic characteristics of CFRP cables, respectively. Zhang and Ying [16] investigated 


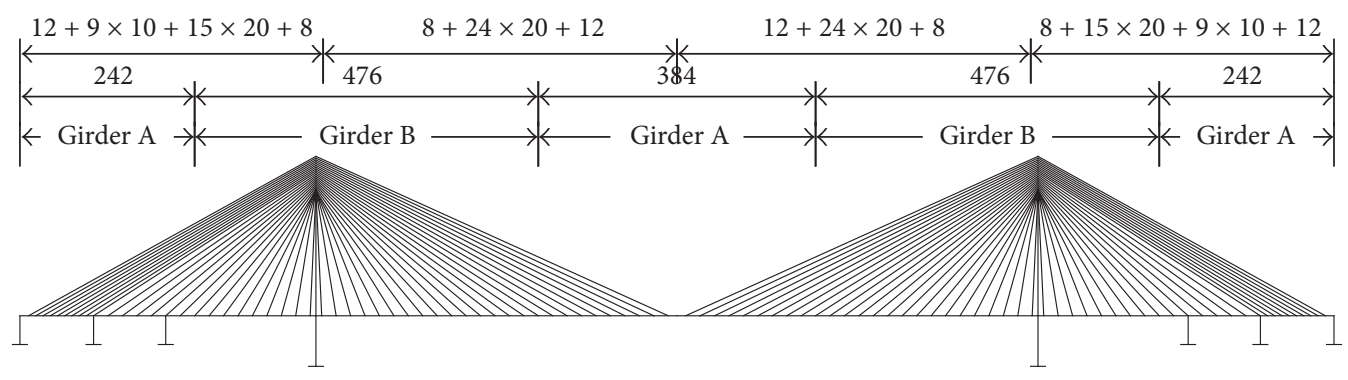

FIGURE 1: General layout of cable-stayed bridges with a $1000 \mathrm{~m}$ span (unit: m).

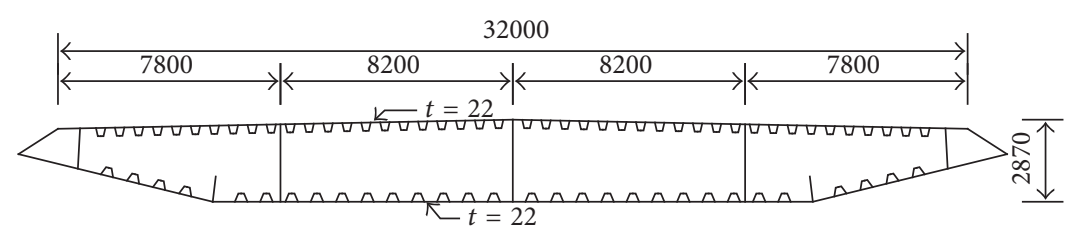

(a) Section of girder $\mathrm{A}$

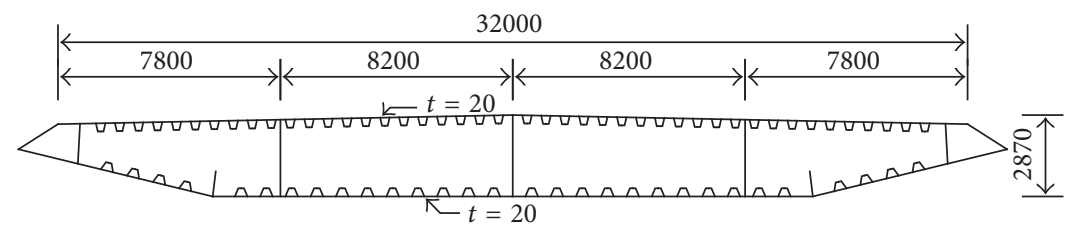

(b) Section of girder $\mathrm{B}$

FIGURE 2: Section of the girder (unit: $\mathrm{mm}$ ).

the aerodynamic stability of cable-stayed bridges using CFRP cables. Kou et al. [17] analyzed the static instability of longspan cable-stayed bridges with CFRP cables under wind load. Xie et al. $[18,19]$ explained the static and dynamic characteristics of a long-span cable-stayed bridge with CFRP cables. Wang et al. (e.g., [20-22]) investigated a $1000 \mathrm{~m}$ scale cable-stayed bridge with hybrid FRP cables. Fang et al. [23] studied the behaviors of a super-long-span prestressed cablestayed bridge with CFRP cables and UHPC girder. Xiong et al. [24] studied the design theory of CFRP and steel composite stay cables. Other scholars (e.g., [25-27]) made more comprehensive studies on the possibility of applying CFRP in long-span bridges.

With increasing span of the cable-stayed bridge, the geometric nonlinear issues become more and more acute, especially the sag effect of steel cable, which even becomes a control factor of designing the cable-stayed bridge. However, very little research on the effects of the geometric nonlinearity on the cable-stayed bridge using CFRP cables was conducted. In this study, the cable-stayed bridges using CFRP and steel cables, respectively, with the same span arrangement were designed. The effects of geometric nonlinearity on the static performance of two cable-stayed bridges were studied. Through comparing the geometric nonlinear effects of the two cable-stayed bridges, the advantages and disadvantages of the cable-stayed bridges using CFRP cables were explored. Although several scholars studied the dynamic characteristics of cable-stayed bridges using CFRP cables before, their research only focused on a special example. In this study, the dynamic characteristics of cable-stayed bridges with different design parameters, including structure system, the numbers of auxiliary piers, and arrangement pattern of cables, were studied. Besides, rational design parameters are also optimized, thus providing reference for the design of cable-stayed bridges using CFRP cables.

\section{Static Performance of the Cable-Stayed Bridge Using CFRP Cables}

Two cable-stayed bridges using CFRP cables and steel cables, respectively, are preliminarily designed, with a $410 \mathrm{~m}+$ $1000 \mathrm{~m}+410 \mathrm{~m}$ span arrangement, as shown in Figure 1. As shown in Figure 2(a), the steel box girder is adopted in this bridge. According to the analysis, the main girder is strengthened in a certain region besides the pylons, which is shown in Figure 2(b). Inverted "Y" type reinforced concrete pylon is designed to bear the forces transferred from cables. The cross section of the pylon is rectangle and the cross section changes gradually from the bottom to the top of the pylon. Figure 3 displays the layout of the pylon. Inclined double plane fan-type cables are adopted in this bridge. The corresponding sectional area of each cable is drawn in Figure 4 and the finished-stage cable forces are shown in Figure 5. Parameters of the main components are presented in Table 1.

As the bridges are not symmetrical about the main pylon, counterbalance weights are set in the intensive-cable region and auxiliary piers region. The specific distribution of the 
TABLE 1: Parameters of main components.

\begin{tabular}{|c|c|c|c|c|c|c|}
\hline $\begin{array}{l}\text { Component } \\
\text { name }\end{array}$ & Material & $\begin{array}{c}\text { Sectional area } \\
\left(\mathrm{m}^{2}\right)\end{array}$ & $\begin{array}{c}\text { Bending moments } \\
\text { of inertia }\left(\mathrm{m}^{4}\right)\end{array}$ & $\begin{array}{c}\text { Transformed unit } \\
\text { weight }\left(\mathrm{kN} / \mathrm{m}^{3}\right)\end{array}$ & $\begin{array}{c}\text { Modulus of } \\
\text { elasticity (MPa) }\end{array}$ & $\begin{array}{c}\text { Coefficient of linear } \\
\text { expansion }\end{array}$ \\
\hline $\begin{array}{l}\text { Upper part of } \\
\text { pylon }\end{array}$ & $\begin{array}{c}\text { Concrete } \\
(f \mathrm{cu} \cdot k=55 \mathrm{MPa})\end{array}$ & $42 \sim 63$ & $396 \sim 633$ & 26 & $3.5 \times 10^{4}$ & $1.0 \times 10^{-5}$ \\
\hline $\begin{array}{l}\text { Middle part of } \\
\text { pylon }\end{array}$ & $\begin{array}{c}\text { Concrete } \\
(f \mathrm{cu} \cdot k=55 \mathrm{MPa})\end{array}$ & $63 \sim 102$ & $938 \sim 2314$ & 26 & $3.5 \times 10^{4}$ & $1.0 \times 10^{-5}$ \\
\hline $\begin{array}{l}\text { Lower part of } \\
\text { pylon }\end{array}$ & $\begin{array}{c}\text { Concrete } \\
(f \mathrm{cu} \cdot k=55 \mathrm{MPa})\end{array}$ & $102 \sim 108$ & $2314 \sim 2542$ & 26 & $3.5 \times 10^{4}$ & $1.0 \times 10^{-5}$ \\
\hline Main girder & $\begin{array}{c}16 \mathrm{Mn} \text { steel } \\
\left(\sigma_{s}=345 \mathrm{MPa}\right)\end{array}$ & $1.47 \sim 2.31$ & $4.0 \sim 6.5$ & 109.9 & $2.1 \times 10^{5}$ & $1.2 \times 10^{-5}$ \\
\hline $\begin{array}{l}\text { CFRP cable } \\
\text { (Per) }\end{array}$ & $\begin{array}{c}\text { CFRP tendons } \\
\left(f_{p k}=2400 \mathrm{MPa}\right)\end{array}$ & $(0.7 \sim 1.25) \times 10^{-2}$ & 0 & 16 & $1.6 \times 10^{5}$ & $0.7 \times 10^{-6}$ \\
\hline $\begin{array}{l}\text { Steel cable } \\
(\text { Per })\end{array}$ & $\begin{array}{l}\text { High-strength steel } \\
\left(f_{p k}=1770 \mathrm{MPa}\right)\end{array}$ & $(0.7 \sim 1.25) \times 10^{-2}$ & 0 & 80 & $2.0 \times 10^{5}$ & $1.2 \times 10^{-5}$ \\
\hline
\end{tabular}

Note. The transformed unit weight of the girder 109.9 includes the weight of stiffening plate; the transformed unit weight of the steel cable 80 includes the weight of protection material.

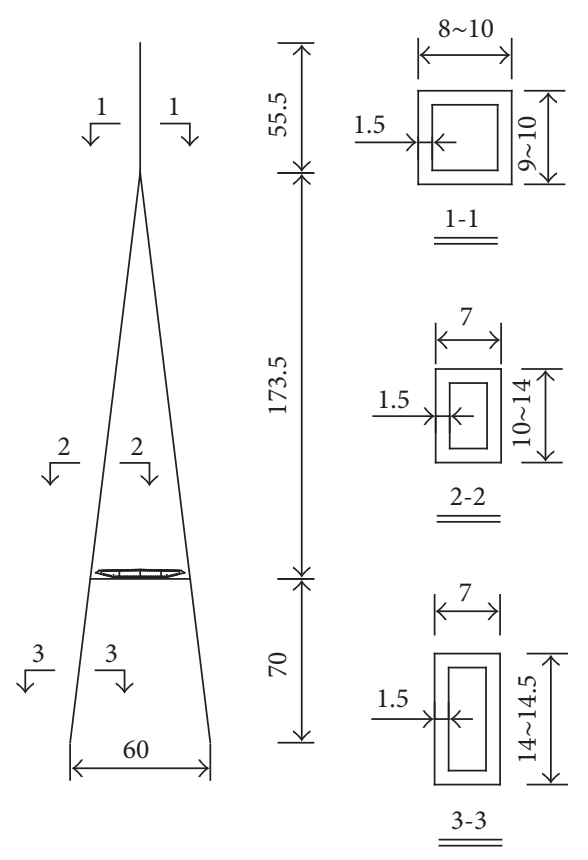

FIGURE 3: Layout of the pylon (unit: m).

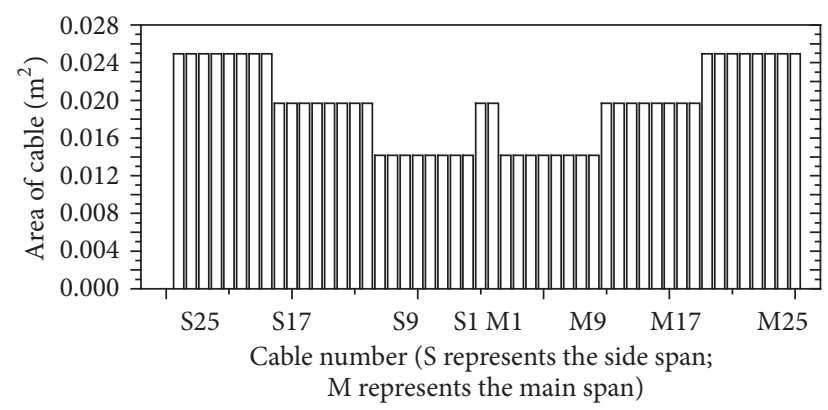

FIgURE 4: Sectional area of the cables.

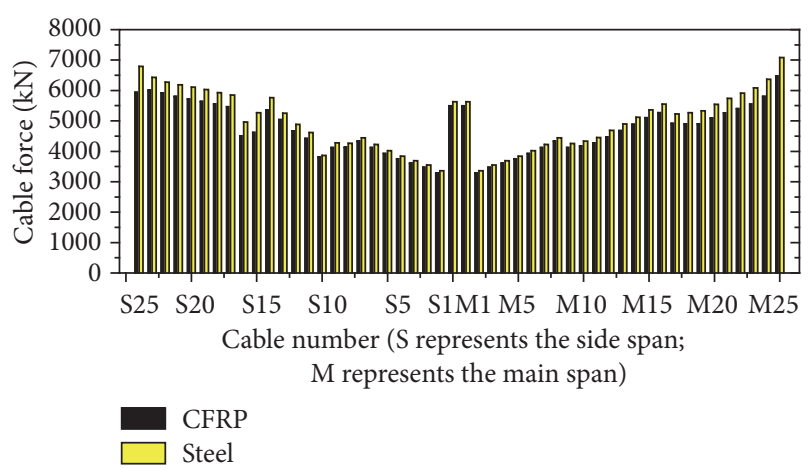

FIGURE 5: Finished-stage cable forces.

counterbalance weights is as follows: In the region of $0 \sim 12 \mathrm{~m}$ from the end of the girder, the average weight is $230 \mathrm{kN} / \mathrm{m}$; in the region of 12 92 m, the average weight is $330 \mathrm{kN} / \mathrm{m}$; in the region of $92 \sim 102 \mathrm{~m}$, the average weight is $280 \mathrm{kN} / \mathrm{m}$; in the region of $102 \sim 122 \mathrm{~m}$, the average weight is $180 \mathrm{kN} / \mathrm{m}$.

Usually, two methods are applied to replace steel cables with CFRP cables. They are equal-strength and equal-stiffness principles, respectively. In terms of equal-strength principle, the design strength of CFRP is usually greater than that of steel due to its much higher tensile strength, and the safety factor is similar to steel, which results in a much smaller sectional area of the CFRP cable than that of the steel one and decreases the stiffness of the whole bridge. But with equal-stiffness principle, larger sectional area of CFRP cable would be required, which is uneconomic. In our paper, a compromise plan for designing the CFRP cable with the same sectional area as the steel cable is adopted. A safety coefficient of 2.5 is selected for steel cables, and then the safety coefficient for CFRP cables is about 3.4 according to the parameters shown in Table 1.

Before discussing the static and dynamic properties of CFRP cable-stayed bridges, the material weight and cost of 
TABLE 2: Material dosages for CFRP and steel cable-stayed bridges.

\begin{tabular}{|c|c|c|c|c|c|c|c|}
\hline \multirow{2}{*}{ Cable type } & \multicolumn{5}{|c|}{ Weight of each component $\left(10^{4} \mathrm{kN}\right)$} & \multirow{2}{*}{ (1)/2) } & \multirow{2}{*}{ (1)/(1) + (2) + (3) } \\
\hline & (1) Cable & (2) Main girder & (3) Second dead load and counter weights & (4) Pylon & (1) $/ 2+(2)+(3)$ & & \\
\hline CFRP & 1.072 & 38.41 & 19.85 & 129.6 & 58.80 & $2.8 \%$ & $1.8 \%$ \\
\hline Steel & 5.360 & 38.41 & 19.85 & 129.6 & 60.94 & $14.0 \%$ & $8.4 \%$ \\
\hline
\end{tabular}

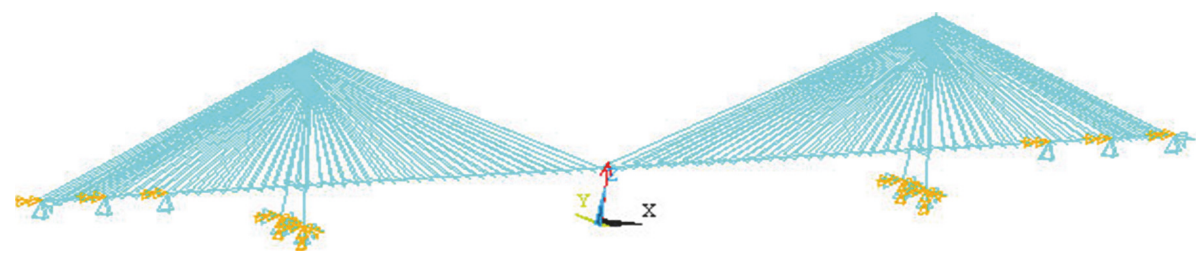

Figure 6: Model for analysis.

CFRP cables versus steel cables are first investigated. The material dosages for the designed CFRP cable-stayed bridge and steel cable-stayed bridge in this paper are calculated and listed in Table 2.

Table 2 shows that, for steel cable-stayed bridge, the selfweight of the cables accounts for approximately $10 \%$ of the total weight of the superstructure. However, the proportion for CFRP cable is just about $2 \%$. With increasing span, this difference will be more and more obvious. Aside from the self-weight of CFRP cable, the relative cost is useful for practical applications. The market prices of imported CFRP cable and steel cable are reported and set to be $25: 1$ per unit weight [21]. As the total weight of CFRP cable in this design is only one-fifth of steel cable's, the total cost of CFRP cable is five times the steel cable's. Along with the localization and application of CFRP, the price ratio will gradually decline. Considering that the cost of maintenance for CFRP cable in the whole life cycle is much less than that for steel cable, the CFRP cable is applicable in super-long bridge practice.

Cable-stayed bridge is a complex structure in which lateral bending and torsion are often coupled together. The entire bridges are modeled by fishbone beam using spatial finite models, by which the girders, pylons, and piers are simulated by three-dimensional beam elements and the cables are simulated by link elements. The sectional properties of the girders, pylons, and piers are modeled in terms of equivalent sectional area and moments of inertia. The analysis model is shown in Figure 6.

2.1. Analysis of Geometrical Nonlinear Influences. The influencing factors of geometric nonlinearity can be classified into three types: sag effect, large deformation effect, and beamcolumn effect. Compared with beam bridges, the effects of geometric nonlinearity on the static performance of cablestayed bridges are greater. The effects of geometric nonlinearity on the static performance of cable-stayed bridges were studied in this paper. Commonly, the sag effect of a cable is considered by an equivalent elastic modulus $E_{\text {eq }}$, which is provided by

$$
E_{\mathrm{eq}}=\frac{E}{\left[1+\left(\gamma_{c}^{2} l^{2} / 12 \sigma_{1}^{3}\right) E\right]},
$$

where $E$ is the modulus of elasticity of the cable, $\gamma_{c}$ is the unit weight of the cable, $l$ is the horizontal projection length of the cable, and $\sigma_{1}$ is the stress of the cable.

The large deformation effect is solved by theoretical formulation of TL or UL methods and the beam-column effect is considered by introducing a geometric stiffness matrix.

According to the Chinese Highway Engineering Technique Standard (JTGB01-2014), the live load (vehicle load) is calculated to be $42 \mathrm{kN} / \mathrm{m}$, with an additional concentrated load of $1440 \mathrm{kN}$ at the midspan.

Analyses were described as follows:

(1) Linear Analysis (L). Any nonlinear factor was not taken into account.

(2) Initial Stress Analysis (IS). Only the geometric stiffness effect produced by cable initial tension was considered, and this effect would be considered in the following analyses.

(3) Sag Effect Analysis (SE). Sag effect was considered, but beam-column effect and large deformation effect were ignored.

(4) Beam-Column Effect Analysis (BE). Beam-column effect was considered, but sag effect and large deformation effect were ignored.

(5) Large Displacement Effect Analysis (LDE). Large deformation effect was considered, but sag effect and beam-column effect were ignored.

(6) Combined Effect Analysis (CE). All nonlinear factors were considered.

According to the six above-mentioned situations, the effects of living load arranged at midspan of the two cablestayed bridges are calculated. The results are presented in Table 3.

According to Table 3, the geometric nonlinear effects on the mechanical behavior of two cable-stayed bridges are discussed using quantitative analysis as follows (by absolute value).

(1) The Influence of Cable Initial Stress. Comparing the results between L and IS, it is found that displacements and internal 
TABLE 3: Comparison of geometric nonlinear static analysis.

\begin{tabular}{|c|c|c|c|c|c|}
\hline \multicolumn{2}{|c|}{ Analysis content } & \multirow{2}{*}{$\begin{array}{l}\text { Displacement (m) } \\
\text { At midspan of main } \\
\text { span (vertical) }\end{array}$} & \multicolumn{2}{|c|}{ Bending moment $\left(10^{4} \mathrm{kN} \cdot \mathrm{m}\right)$} & \multirow{2}{*}{$\begin{array}{c}\text { Axial force of } \\
\text { girder }\left(10^{4} \mathrm{kN}\right) \\
\text { At the pylon }\end{array}$} \\
\hline & & & $\begin{array}{l}\text { At midspan of main } \\
\text { span }\end{array}$ & $\begin{array}{c}\text { At bottom of the } \\
\text { pylon }\end{array}$ & \\
\hline \multirow{6}{*}{ CFRP cables } & $\mathrm{L}$ & -1.406 & 7.57 & 74.2 & -2.58 \\
\hline & IS & -1.367 & 7.42 & 71.6 & -2.51 \\
\hline & SE & -1.364 & 7.41 & 71.4 & -2.49 \\
\hline & $\mathrm{BE}$ & -1.429 & 7.60 & 73.4 & -2.62 \\
\hline & LDE & -1.369 & 7.40 & 72.1 & -2.51 \\
\hline & $\mathrm{CE}$ & -1.432 & 7.62 & 74.2 & -2.96 \\
\hline \multirow{6}{*}{ Steel cables } & $\mathrm{L}$ & -1.175 & 6.92 & 63.6 & -2.62 \\
\hline & IS & -1.154 & 6.81 & 61.8 & -2.56 \\
\hline & SE & -1.240 & 7.11 & 63.8 & -2.54 \\
\hline & $\mathrm{BE}$ & -1.196 & 6.97 & 63.0 & -2.66 \\
\hline & LDE & -1.156 & 6.81 & 62.1 & -2.56 \\
\hline & $\mathrm{CE}$ & -1.331 & 7.39 & 66.4 & -3.01 \\
\hline
\end{tabular}

forces of the two cable-stayed bridges decrease when initial tensions of cables are considered. This is because geometrical stiffness, provided by the initial tension, increases the structural stiffness.

(2) The Influence of Sag Effect. Comparing the results between SE and IS, it is found that displacements and bending moments of the cable-stayed bridges using CFRP cables exhibit a little difference, whereas the displacements and bending moments at the midspan of the steel cable-stayed bridge increase by $7.5 \%$ and $4.4 \%$, respectively, when the sag effect is taken into account, indicating that CFRP cable displays a smaller sag effect than steel cable.

(3) The Influence of Beam-Column Effect. Comparing the results between $\mathrm{BE}$ and $\mathrm{IS}$, it is found that displacements and internal forces of the two cable-stayed bridges increase by $2 \%$ to $6 \%$ after considering the beam-column effect, demonstrating the significant influence of the beam-column effect on both cable-stayed bridges.

(4) The Influence of Large Displacement Effect. Comparing the results between LDE and IS, it is found that the bending moments at the bottom of the pylon slightly increase, whereas the structural effects of other parts change a little, indicating that the influence of the large displacement effect is minor under live load.

(5) The Combined Effect Influence. Comparing the results of CE and IS, the nonlinear effect of the steel cable-stayed bridge is very significant, whereas most effects of CFRP cablestayed bridge change slightly, except for the axial force of the main girder at the pylon when taking into account all of the geometric nonlinearities.

(6) Comparing the Results of the Two Cable-Stayed Bridges. Comparing the results of the two cable-stayed bridges, most structural effects of CFRP cable-stayed bridges are greater than those of steel cable-stayed bridges, except for the axial force of the main girder at the pylon. This is because the elastic modulus of the CFRP cable is $20 \%$ less than that of steel cable, but the former is $8 \%$ less than the latter after considering the sag effect. With increasing bridge span, the greater the sag effect, the less the equivalent elastic modulus. Hence, when designing a CFRP cable-stayed bridge, the design cable force should be larger than that of steel cable-stayed bridge to eliminate the difference and to ensure the serviceability of CFRP cable-stayed bridge. Note that the above analysis only considered the vehicle loads completely distributed in the midspan. However, for super-long-span bridges, the vehicle loads only account for a quite small portion of the dead load. Hence, the geometric nonlinear properties under dead load are undoubtedly more obvious than under vehicle loads. For this reason, the geometric nonlinear properties in the construction stages are of great importance and need more attention.

2.2. Analysis of the Live Load Effect of Two Cable-Stayed Bridges. Given the geometry nonlinearity effect, the linear superposition principle is not applicable for long-span cablestayed bridges. Therefore, the traditional influence lineloading algorithm cannot be used for the analysis of live load effect. However, the live load accounts for only $15 \%$ of the dead load of superstructures for long-span bridges, so the dead load can be used as its initial state to calculate the live load effect. This method is called the second-order theory for live load effect calculation.

The CFRP cable-stayed bridge was calculated by the second-order theory analysis and linear analysis methods. Figures 7, 8, and 9 show envelope diagrams of bending moments, axial forces, and deflections of the girder, respectively.

Figures 7-9 show that the results of the linear analysis method are less than those by the second-order theory analysis method. However, their differences are small because the sag effect of CFRP cable-stayed bridge is low, thereby leading to a very small total geometric nonlinear effect.

Figures 7 and 8 also show that the girders' bending moment of CFRP cable-stayed bridge is greater than that of steel cable-stayed bridge because equivalent elastic modulus 


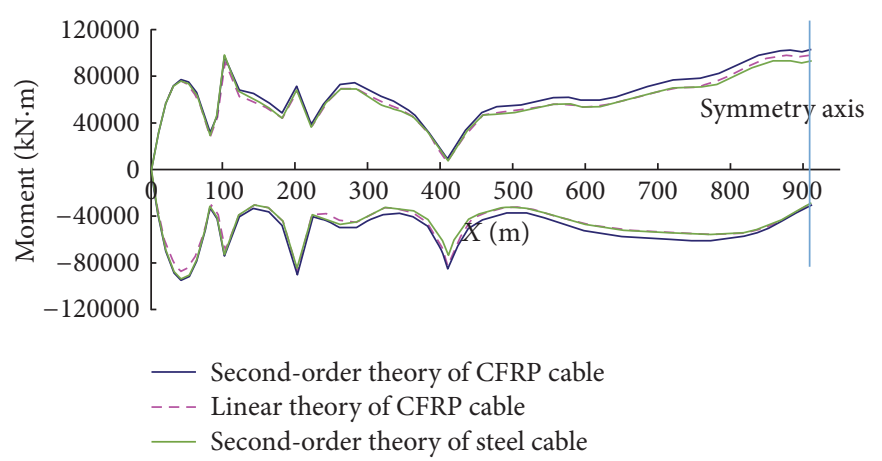

FIGURE 7: Envelope diagram of girder's bending moments.

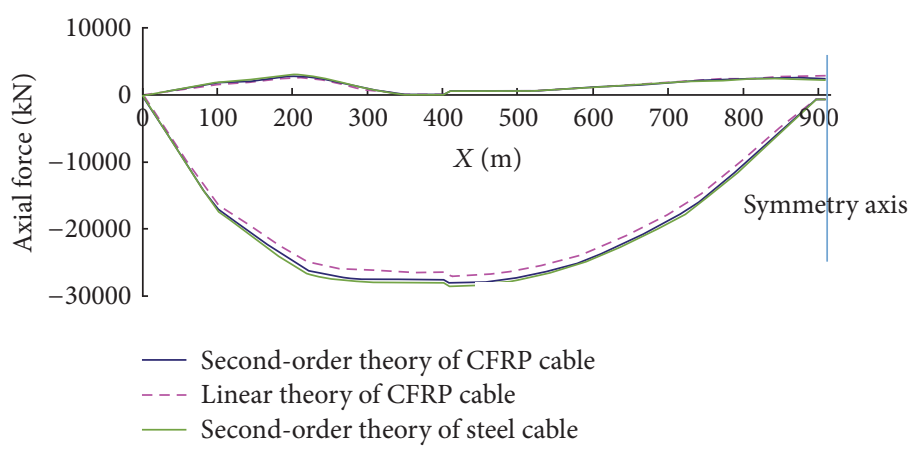

FIGURE 8: Envelope diagram of girder's axial forces.

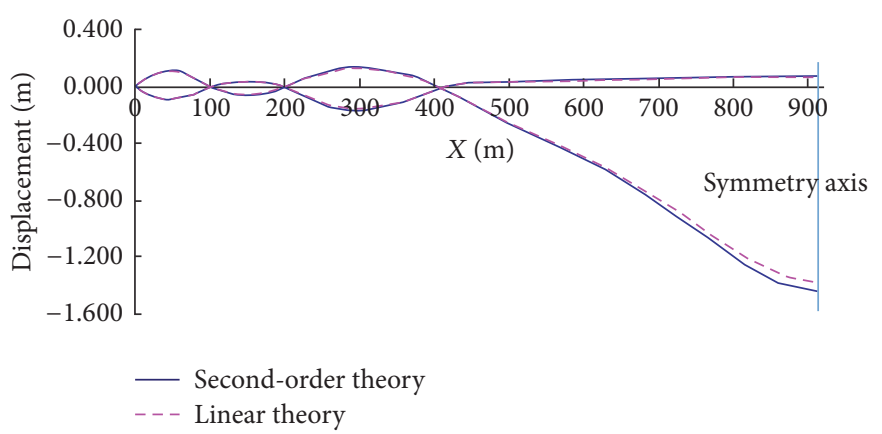

FIGURE 9: Envelope diagram of girder's vertical displacements.

of CFRP cables is less than that of steel cables when the span is within $1000 \mathrm{~m}$. However, girders' axial forces of the former are less than the latter, as the sag effect of steel cables reduces their obliquity at the beam end, thereby causing an increase in the horizontal component.

\subsection{Temperature Effect Analysis of CFRP Cable-Stayed Bridge.} The linear expansion coefficient of CFRP is approximately $1 / 14$ of steel. When structures are made of the same material, the smaller the linear expansion coefficient, the smaller the temperature effect. To evaluate the temperature susceptibility of the CFRP cable-stayed bridge, the temperature effect of the two cable-stayed bridges mentioned before with different structure systems was examined. Restraint stiffness is $12,000 \mathrm{kN} / \mathrm{m}$ in the tower-beam elastic restraint system. According to Guidelines for Design of Highway
Cables-Stayed Bridge (JTG/T D65-01-2007), the combination of temperatures is as follows: the temperature of girder rise $20^{\circ} \mathrm{C}+$ the temperature of pylon rise $15^{\circ} \mathrm{C}+$ the temperature of cables rise $30^{\circ} \mathrm{C}$. Temperature effects of different structural systems are shown in Table 4.

A significant difference can be found by comparing the results of the two cable-stayed bridges. The deformations of CFRP cables are small because the linear expansion coefficient value of CFRP is much less than that of steel. Correspondingly, the tension forces increase rather than decrease because of the uncoordinated deformation. Moreover, the deflections of the girder are upward and the bending moments of the girder at the pylon are positive. On the contrary, the elongation of the steel cable is large, resulting in the decrease of cable tension, downward deflection of the girder, and a great negative bending moment at the pylon. 
TABLE 4: Temperature effects of different structural systems.

\begin{tabular}{|c|c|c|c|c|c|}
\hline Cable type & $\begin{array}{l}\text { Sectional position (force or } \\
\text { displacement) }\end{array}$ & $\begin{array}{c}\text { The floating } \\
\text { system }\end{array}$ & $\begin{array}{c}\text { The tower-beam } \\
\text { elastic restraint } \\
\text { system }\end{array}$ & $\begin{array}{l}\text { The semifloating } \\
\text { system }\end{array}$ & $\begin{array}{l}\text { Rigid-frame } \\
\text { system }\end{array}$ \\
\hline \multirow{5}{*}{ CFRP cables } & $\begin{array}{l}\text { Girder's bending moment at } \\
\text { the pylon }(\mathrm{kN} \cdot \mathrm{m})\end{array}$ & 20387 & 20359 & 24125 & 12373 \\
\hline & $\begin{array}{l}\text { Bending moment at bottom of } \\
\text { the pylon }(\mathrm{kN} \cdot \mathrm{m})\end{array}$ & $-4.062 \times 10^{5}$ & $-4.524 \times 10^{5}$ & $-4.064 \times 10^{5}$ & $-2.270 \times 10^{6}$ \\
\hline & Displacement at midspan (m) & 0.383 & 0.383 & 0.384 & 0.326 \\
\hline & $\begin{array}{l}\text { Horizontal displacement of } \\
\text { beam end }(\mathrm{m})\end{array}$ & -0.179 & -0.178 & -0.179 & -0.129 \\
\hline & $\begin{array}{l}\text { Cable's axial force at the pylon } \\
(\mathrm{kN})\end{array}$ & 167 & 167 & 204 & 220 \\
\hline \multirow{5}{*}{ Steel cables } & $\begin{array}{l}\text { Girder's bending moment at } \\
\text { the tower }(\mathrm{kN} \cdot \mathrm{m})\end{array}$ & -35196 & -35227 & -38490 & -67794 \\
\hline & $\begin{array}{l}\text { Bending moment at bottom of } \\
\text { the pylon }(\mathrm{kN} \cdot \mathrm{m})\end{array}$ & $-3.868 \times 10^{4}$ & $-9.010 \times 10^{4}$ & $-3.854 \times 10^{4}$ & $-2.106 \times 10^{6}$ \\
\hline & Displacement at midspan (m) & -0.474 & -0.479 & -0.474 & -0.542 \\
\hline & $\begin{array}{l}\text { Horizontal displacement of } \\
\text { beam end }(\mathrm{m})\end{array}$ & -0.182 & -0.181 & -0.182 & -0.126 \\
\hline & $\begin{array}{l}\text { Cable's axial force at the pylon } \\
(\mathrm{kN})\end{array}$ & -359 & -359 & -395 & -349 \\
\hline
\end{tabular}

To sum up, the girder's bending moment at the pylon and displacement at midspan of CFRP cable-stayed bridge due to temperature are less than those of the steel cable-stayed bridge, which is beneficial for the service performance of the whole bridge.

\section{Dynamic Characteristics of CFRP Cable-Stayed Bridge}

3.1. Dynamic Characteristics of Cable-Stayed Bridge Using Different Kinds of Stay Cables. To analyze the dynamic characteristics of cable-stayed bridge using different kinds of stay cables, the bridges with the same span arrangement as that in static analysis were adopted. Using FEM model, the first 16 orders of vibration mode and the corresponding frequency considering or not considering initial stress of the cable-stayed bridges are calculated, respectively, and listed in Table 5. The first 20-order frequencies of two cable-stayed bridges are shown in Figures 10 and 11.

To verify the rationality of the preliminary design of the bridges and the reliability of calculation, the main fundamental frequencies of the two cable-stayed bridges with similar main span were listed for comparison. For a cablestayed bridge with span arrangement of $76 m+100 m+298 m$ $+1008 m+298 m+100 m+76 m$ [23], the fundamental frequencies of lateral bending, vertical bending, and torsional modes are $0.129,0.201$, and $0.547 \mathrm{~Hz}$, respectively. For a cablestayed bridge with a span arrangement of $450 \mathrm{~m}+1000 \mathrm{~m}+$ $450 \mathrm{~m}$ [28], the fundamental frequencies of lateral bending, vertical bending, and torsional modes are 0.1016, 0.1842, and $0.4630 \mathrm{~Hz}$, respectively. These indicate that the design is reasonable and the results of the dynamic characteristics are credible. Comparing the results of the two cable-stayed bridges, the researchers found the following.

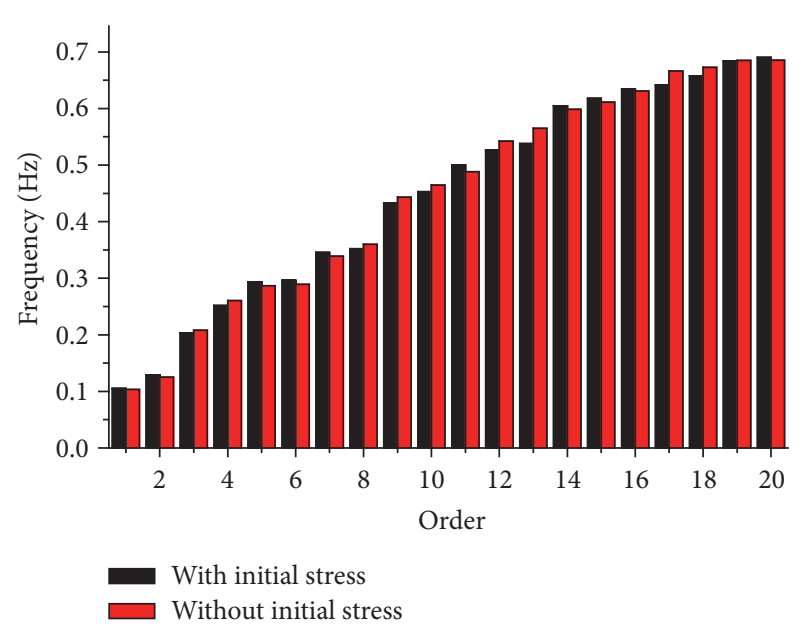

FIGURE 10: First 20-order frequencies of CFRP cable-stayed bridge.

(1) The frequencies decrease if initial stress is considered. This is because the main girder and pylon are mainly compressed, and their structural stiffnesses decrease after considering initial stress. However, the difference between the two results is unobvious.

(2) The vertical bending natural vibration frequencies of the cable-stayed bridge using CFRP cables are lower than those using steel cables because the elastic modulus of the CFRP cable is smaller than that of steel cable. This leads to smaller elastic support stiffness for the main girder, which is in accordance with the static characteristic. It is also found that, with increasing span of the bridge, the sag effect increases, and the equivalent elastic modulus decreases. However, if the span is greater than a certain value, the 
TABLE 5: Dynamic performance of the two cable-stayed bridges.

\begin{tabular}{|c|c|c|c|c|c|c|c|c|}
\hline \multirow[b]{3}{*}{ Order } & \multicolumn{7}{|c|}{ Frequency $(\mathrm{Hz})$} & \multirow{3}{*}{ Modal characteristics } \\
\hline & \multicolumn{2}{|c|}{ CFRP cable-stayed bridge } & \multicolumn{5}{|c|}{ Steel cable-stayed bridge } & \\
\hline & $\begin{array}{c}\text { With } \\
\text { initial } \\
\text { stress }\end{array}$ & $\begin{array}{c}\text { Without } \\
\text { initial } \\
\text { stress }\end{array}$ & $\begin{array}{c}\text { The } \\
\text { difference } \\
(\%)\end{array}$ & Order & $\begin{array}{l}\text { With } \\
\text { initial } \\
\text { stress }\end{array}$ & $\begin{array}{l}\text { Without } \\
\text { initial stress }\end{array}$ & $\begin{array}{c}\text { The } \\
\text { difference } \\
(\%)\end{array}$ & \\
\hline 1 & 0.1012 & 0.1067 & 5.4 & 1 & 0.0988 & 0.1045 & 5.8 & $\begin{array}{c}\text { Longitudinal floating }+ \\
\text { vertical bending of pylon }\end{array}$ \\
\hline 2 & 0.1290 & 0.1292 & 0.2 & 2 & 0.1248 & 0.1253 & 0.4 & First lateral lending \\
\hline 3 & 0.2028 & 0.2046 & 0.9 & 3 & 0.2075 & 0.2095 & 1.0 & First vertical bending \\
\hline 4 & 0.2493 & 0.2529 & 1.4 & 4 & 0.2575 & 0.2614 & 1.5 & Second vertical bending \\
\hline 5 & 0.3403 & 0.3429 & 0.8 & 5 & 0.3338 & 0.3366 & 0.8 & Second lateral bending \\
\hline 6 & 0.3463 & 0.3556 & 2.7 & 6 & 0.3546 & 0.3640 & 2.7 & Third vertical bending \\
\hline 7 & 0.4227 & 0.4352 & 3.0 & 7 & 0.4346 & 0.4470 & 2.9 & Fourth vertical bending \\
\hline 8 & 0.4493 & 0.4621 & 2.8 & 10 & 0.4612 & 0.4738 & 2.7 & Fifth vertical bending \\
\hline 9 & 0.4776 & 0.4792 & 0.3 & 8 & 0.4568 & 0.4594 & 0.6 & $\begin{array}{l}\text { Synchrony lateral bending } \\
\text { of pylon }\end{array}$ \\
\hline 10 & 0.4800 & 0.4816 & 0.3 & 9 & 0.4586 & 0.4612 & 0.6 & $\begin{array}{l}\text { Reverse lateral bending of } \\
\text { pylon }\end{array}$ \\
\hline 11 & 0.5154 & 0.5325 & 3.3 & 11 & 0.5318 & 0.5486 & 3.2 & Sixth vertical bending \\
\hline 12 & 0.5277 & 0.5412 & 2.6 & 13 & 0.5529 & 0.5675 & 2.6 & Vertical bending \\
\hline 13 & 0.5533 & 0.5625 & 1.7 & 12 & 0.5432 & 0.5529 & 1.8 & $\begin{array}{l}\text { First torsion }+ \text { lateral } \\
\text { bending }\end{array}$ \\
\hline 14 & 0.5703 & 0.5855 & 2.7 & 14 & 0.5595 & 0.5743 & 2.6 & $\begin{array}{l}\text { Reverse lateral bending of } \\
\text { pylon }+ \text { torsion }\end{array}$ \\
\hline 15 & 0.5906 & 0.6081 & 3.0 & 16 & 0.6160 & 0.6338 & 2.9 & Vertical bending \\
\hline 16 & 0.5912 & 0.5949 & 0.6 & 15 & 0.5816 & 0.5849 & 0.6 & First torsion \\
\hline
\end{tabular}

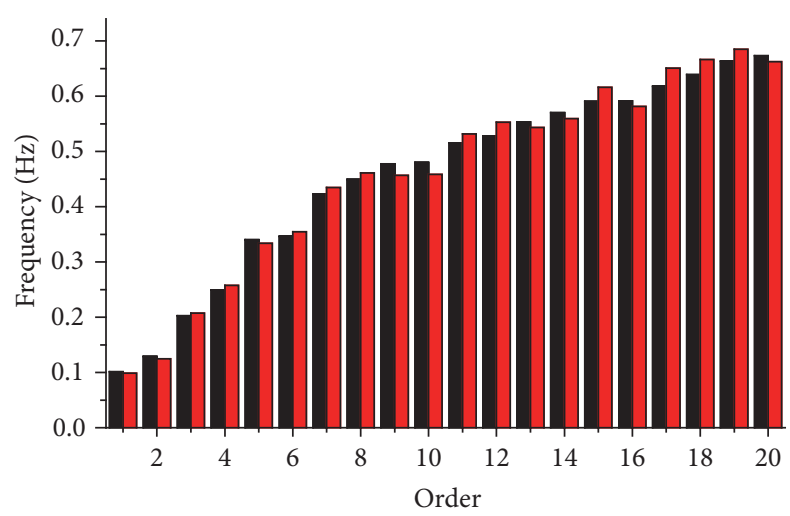

CFRP cable

Steel cable

FIGURE 11: First 20-order frequencies of two cable-stayed bridges.

vertical bending natural vibration frequency of CFRP cablestayed bridge will be higher than steel cable-stayed bridges.

(3) The torsional natural vibration frequency of CFRP cable-stayed bridge is a bit higher than that of steel cablestayed bridge because the CFRP cables are lighter and provide a smaller mass moment of inertia. With increasing span, the equivalent elastic modulus of CFRP cables increases faster than that of steel cables. Hence, the torsional natural vibration frequency of CFRP cable-stayed bridge will be much higher than that of steel cable-stayed bridge, which is beneficial for improving the flutter critical wind speed.

\subsection{Analysis of the Parameter Influencing Dynamic Characteristics of CFRP Cable-Stayed Bridge}

3.2.1. The Influence of Structural System. The common structural systems of long-span cable-stayed bridges can be classified into four types: full-floating system, half-floating system, rigid-frame system, and tower-beam elastic restraint system. The dynamic properties of different kinds of structural systems of the CFRP cable-stayed bridge are compared in this section. The longitudinal elastic restraint stiffness is $12,000 \mathrm{kN} / \mathrm{m}$ for tower-beam elastic restraint system. Table 6 lists the main vibration modes and corresponding frequencies.

Table 6 shows that the natural vibration frequency values of the full-floating system are very close to those of the halffloating system. Given that the longitudinal displacement is not constrained, the natural vibration frequency of the firstorder longitudinal floating mode is relatively low. This is essential to reduce the responses of the structure under horizontal seismic action. But with increasing span, displacement response at the beam end will become too large to accept. The vertical bending natural vibration frequency changes unobviously after setting a vertical bearing, indicating that 
TABLE 6: Dynamic characteristics of CFRP cable-stayed bridge with different structural systems.

\begin{tabular}{|c|c|c|c|c|c|c|c|c|}
\hline \multicolumn{2}{|c|}{ Full-floating system } & \multicolumn{2}{|c|}{ Half-floating system } & \multicolumn{2}{|c|}{ Rigid-frame system } & \multicolumn{2}{|c|}{$\begin{array}{l}\text { Tower-beam elastic } \\
\text { restraint system }\end{array}$} & \multirow[t]{2}{*}{ Modal characteristics } \\
\hline Order & $\begin{array}{c}\text { Frequency } \\
(\mathrm{Hz})\end{array}$ & Order & $\begin{array}{l}\text { Frequency } \\
(\mathrm{Hz})\end{array}$ & Order & $\begin{array}{l}\text { Frequency } \\
(\mathrm{Hz})\end{array}$ & Order & $\begin{array}{l}\text { Frequency } \\
(\mathrm{Hz})\end{array}$ & \\
\hline 1 & 0.0731 & 1 & 0.0731 & & & 1 & 0.1067 & $\begin{array}{l}\text { Longitudinal floating + vertical } \\
\text { bending of pylon }\end{array}$ \\
\hline 2 & 0.1291 & 2 & 0.1295 & 1 & 0.1365 & 2 & 0.1292 & First lateral bending \\
\hline 3 & 0.2046 & 3 & 0.2046 & 2 & 0.2050 & 3 & 0.2046 & First vertical bending \\
\hline 13 & 0.5625 & 13 & 0.5636 & 15 & 0.6650 & 13 & 0.5625 & First torsion + lateral bending \\
\hline 15 & 0.5949 & 15 & 0.5984 & 12 & 0.5853 & 15 & 0.5949 & First torsion \\
\hline
\end{tabular}

TABLE 7: Dynamic characteristics of CFRP cable-stayed bridge with different numbers of auxiliary piers.

\begin{tabular}{|c|c|c|c|c|c|c|c|c|}
\hline \multicolumn{2}{|c|}{ No auxiliary pier } & \multicolumn{2}{|c|}{1 auxiliary pier } & \multicolumn{2}{|c|}{2 auxiliary piers } & \multicolumn{2}{|c|}{3 auxiliary piers } & \multirow{2}{*}{ Modal characteristics } \\
\hline Order & $\begin{array}{l}\text { Frequency } \\
(\mathrm{Hz})\end{array}$ & Order & $\begin{array}{c}\text { Frequency } \\
(\mathrm{Hz})\end{array}$ & Order & $\begin{array}{c}\text { Frequency } \\
(\mathrm{Hz})\end{array}$ & Order & $\begin{array}{l}\text { Frequency } \\
(\mathrm{Hz})\end{array}$ & \\
\hline 1 & 0.1023 & 1 & 0.1067 & 1 & 0.1067 & 1 & 0.1076 & $\begin{array}{l}\text { Longitudinal floating }+ \\
\text { vertical bending of pylon }\end{array}$ \\
\hline 2 & 0.1121 & 2 & 0.1286 & 2 & 0.1292 & 2 & 0.1351 & First lateral bending \\
\hline 3 & 0.1151 & 3 & 0.1673 & 3 & 0.2046 & 3 & 0.2094 & First vertical bending \\
\hline 7 & 0.3578 & 7 & 0.3762 & & & & & $\begin{array}{c}\text { Second vertical bending }+ \\
\text { side-span first vertical } \\
\text { bending }\end{array}$ \\
\hline 9 & 0.4243 & & & & & & & $\begin{array}{l}\text { Side-span synchrony first } \\
\text { lateral bending }\end{array}$ \\
\hline 12 & 0.4639 & & & & & & & $\begin{array}{l}\text { Side-span reverse first } \\
\text { lateral bending }\end{array}$ \\
\hline 18 & 0.5628 & 15 & 0.5625 & 13 & 0.5625 & 13 & 0.5632 & $\begin{array}{l}\text { First torsion }+ \text { lateral } \\
\text { bending }\end{array}$ \\
\hline 21 & 0.5956 & 17 & 0.5946 & 15 & 0.5949 & 15 & 0.5980 & First torsion \\
\hline
\end{tabular}

setting a vertical bearing has little impact on the overall stiffness. The longitudinal stiffness of the rigid-frame system is the largest, so the longitudinal vibration mode does not appear alone. Moreover, the lateral bending and torsional natural vibration frequencies visibly increase at the same time. Comparing the full-floating system and the half-floating system, only the longitudinal floating mode natural vibration frequency of tower-beam elastic restraint system increases whereas other frequencies change slightly. The tower-beam elastic restraint system meets the requirements of bearing capacity and deformation of the cable-stayed bridge at the same time; therefore, it is applicable in super-long-span cablestayed bridge.

\subsubsection{The Influence of the Numbers of Side-Span Auxiliary} Piers. The influence of the numbers of side-span auxiliary piers on structure dynamic performance is analyzed in the following. Table 7 lists the main vibration modes and the corresponding frequencies.

Table 7 shows that the first lateral and vertical natural vibration frequencies visibly increase when one auxiliary pier is set at two side spans. When two auxiliary piers are set up, the first lateral and vertical natural vibration frequencies further increase. However, when three auxiliary piers are set, only a slight increase is observed. Notably, the increase of lateral bending natural vibration frequency results from setting a lateral horizontal restraint for the girder at the auxiliary pier.

3.2.3. The Influence of Space Arrangement Type of Stay Cables. Single-cable plane and double-cable plane are two general arrangements in cable-stayed bridges. The double cable plane includes parallel double cable plane and inclined double cable plane. The influences of arrangement forms on structure dynamic performance are analyzed in this section. Table 8 lists the main vibration modes and the corresponding frequencies. The torsional vibration mode of the cable-stayed bridges with different cable planes is shown in Figure 12.

Table 8 shows that lateral bending natural vibration frequencies of pylon with parallel cable plane are smaller than those with inclined cable plane. This is because the " $H$ " pylon is selected for parallel plane cable and its lateral bending stiffness is smaller than the " $Y$ " pylon. In addition, the first torsional natural vibration frequency of the main girder with inclined cable plane is approximately $20 \%$ higher than that with the parallel cable plane because when torsional deformation of the main girder occurs, the two pillars of the " $\mathrm{H}$ " pylon are in harmony with the expansion deformation 
TABle 8: Dynamic characteristics of the two cable-stayed bridges with different types of cable plane.

\begin{tabular}{|c|c|c|c|c|c|c|c|c|}
\hline \multicolumn{8}{|c|}{ Frequency $(\mathrm{Hz})$} & \multirow{3}{*}{ Modal characteristics } \\
\hline \multicolumn{4}{|c|}{ CFRP cable-stayed bridge } & \multicolumn{4}{|c|}{ Steel cable-stayed bridge } & \\
\hline Order & Inclined plane & Order & Parallel plane & Order & Inclined plane & Order & Parallel plane & \\
\hline 1 & 0.1067 & 1 & 0.1053 & 1 & 0.1045 & 1 & 0.1032 & $\begin{array}{c}\text { Longitudinal floating }+ \\
\text { vertical bending of pylon }\end{array}$ \\
\hline 2 & 0.1292 & 2 & 0.1292 & 2 & 0.1253 & 2 & 0.1254 & First lateral bending \\
\hline 3 & 0.2046 & 3 & 0.2031 & 3 & 0.2095 & 3 & 0.2080 & First vertical bending \\
\hline 13 & 0.5625 & & & 12 & 0.5529 & & & $\begin{array}{l}\text { First torsion }+ \text { lateral } \\
\text { bending }\end{array}$ \\
\hline 15 & 0.5949 & 11 & 0.4999 & 15 & 0.5849 & 11 & 0.4883 & First torsion \\
\hline
\end{tabular}

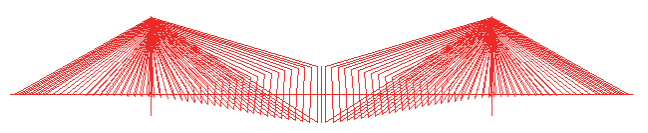

(a) Inclined cable plane

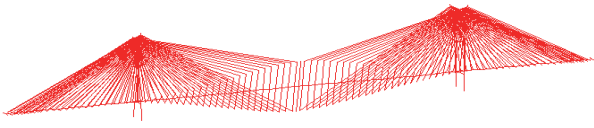

(b) Parallel cable plane

FIGURE 12: Torsional vibration mode of the cable-stayed bridges with different cable planes.

of the parallel cable by reverse bending, thereby resulting in a reduction in torsional rigidity provided by the stay cable. Given that higher torsional fundamental frequency is beneficial in improving wind resistance stability of cablestayed bridge, an inclined cable plane arrangement type is suggested to be selected in a large-span cable-stayed bridge.

\section{Conclusions}

Two $1000 \mathrm{~m}$ span cable-stayed bridges using CFRP cable and steel cables, respectively, were preliminarily designed. The static and dynamic performances of the two kinds of bridges were analyzed using FEM. The effects of geometric nonlinear factors on static performance and the influences of design parameters, including different structural systems, the numbers of auxiliary piers, and the space arrangement types of cable, on the dynamic performance of the cable-stayed bridge using CFRP cables were also studied. The following specific conclusions can be drawn.

(1) The displacements of the cable-stayed bridges using CFRP cables exhibit a little difference, whereas the displacements at the midspan of steel cable-stayed bridge increase by $7.5 \%$, when the sag effect is taken into account.. With increasing span, the sag effect of steel cable will be larger than that of CFRP cable. Besides, the beam-column effects of the two bridges are both great, whereas the large displacement effects are relatively small.

(2) The girder's bending moment at the pylon and displacement at midspan of CFRP cable-stayed bridge due to temperature are less than those of steel cable-stayed bridge, which is beneficial for the service performance of the whole bridge.

(3) The vertical bending natural vibration frequency of the CFRP cable-stayed bridge is generally lower than that of steel cable-stayed bridge, whereas the torsion natural vibration frequency of the former is higher than that of the latter. A higher torsion-bend frequency ratio is beneficial for enhancing the critical flutter wind speed.

(4) Comparing the full-floating system and the halffloating system, only the longitudinal floating mode natural vibration frequency of the tower-beam elastic restraint system increases, whereas the other frequencies change slightly. Obviously, the tower-beam elastic restraint system is applicable in the super-long-span cable-stayed bridge.

(5) Setting up one or two auxiliary piers can improve the lateral and vertical fundamental frequencies. However, when three auxiliary piers are set up, only a slight increase is observed. Therefore, setting up 2-3 auxiliary piers is enough and the numbers of piers should not be more than 3 .

(6) The first torsional natural vibration frequency of the main girder with inclined cable plane is approximately $20 \%$ higher than that with parallel cable plane. Considering that the higher torsional natural vibration frequency can improve wind resistance stability of cable-stayed bridge, the inclined cable plane is more suitable for long-span cable-stayed bridge.

\section{Conflicts of Interest}

The authors declare that they have no conflicts of interest.

\section{Acknowledgments}

The authors gratefully acknowledge the National Natural Science Foundation of China (no. 51778059) for their support.

\section{References}

[1] U. Meier and H. Meier, "CFRP finds use in cable support for bridge," Modern Plastics, vol. 73, no. 4, pp. 87-91, 1996.

[2] U. Meier, "Structural tensile elements made of advanced composite materials," Structural Engineering International, vol. 9, no. 4, pp. 281-285, 1999. 
[3] U. Meier, "Carbon fiber reinforced polymer cables: why? why not? what if?" Arabian Journal for Science and Engineering, vol. 37, no. 2, pp. 399-411, 2012.

[4] W. Nik and K. Pascal, "Carbon fiber products (CFP): a construction material for the next century," in Proceedings of the 13th FIP Congress, pp. 69-72, 1998.

[5] V. M. Karbhari and F. Seible, "Fiber-reinforced polymer composites for civil infrastructure in the USA," Structural Engineering International, vol. 9, no. 4, pp. 274-277, 1999.

[6] C. J. Burgoyne, "Advanced composites in civil engineering in europe," Structural Engineering International, vol. 9, no. 4, pp. 267-273, 1999.

[7] F. Lanza di Scalea, V. M. Karbhari, and F. Seible, "The I5/Gilman advanced technology bridge project," in Smart Structures and Materials 2000: Smart Systems for Bridges, Structures, and Highways, pp. 10-17, 2000.

[8] Z. Lu and K. Mei, "First application of CFRP cables for a cablestayed bridge in China," China Civil Engineering Journal, vol. 40, no. 1, pp. 54-59, 2007.

[9] K. H. Mei, Study on the cable-stayed bridge with CFRP cables [Ph.D. thesis], Southeast University, Nanjing, China, 2005.

[10] M. A. Khalifa, O. A. Hodhod, and M. A. Zaki, "Analysis and design methodology for an FRP cable-stayed pedestrian bridge," Composites Part B: Engineering, vol. 27, no. 3-4, pp. 307317, 1996.

[11] S. Adanur and M. Gunaydin, "Stochastic seismic analysis of a cable-stayed bridge using CFRP cables," in Proceedings of the 2nd International Balkans Conferences on Challenges of Civil Engineering (BCCCE '13), Tirana, Albania, 2013.

[12] S. Adanur, M. Gunaydin, A. C. Altunisik, and B. Sevim, "Dynamic behavior of a cable stayed bridge using CFRP cables," in Proceedings of the Vienna Congress on Recent Advances in Earthquake Engineering and Structural Dynamics (VEESD '13), C. Adam, R. Heuer, W. Lenhardt, and C. Schranz, Eds., Vienna, Austria, 2013.

[13] S. Cheng and D. T. Lau, "Impact of using CFRP cables on the dynamic behaviour of cable-stayed bridges," IABSE Symposium Report, vol. 92, no. 13, pp. 19-26, 2006.

[14] K. H. Mei and Z. T. Lu, "Static characteristic analysis of CFRP cables," China Journal of Highway and Transport, vol. 17, no. 2, pp. 43-45, 2004.

[15] X. Xie, H. Zhang, Y.-F. Zhu, and C.-H. Kou, "Dynamic characteristics of CFRP cables under lateral wind load," Journal of Zhejiang University, vol. 42, no. 1, pp. 145-151, 2008.

[16] X.-J. Zhang and L.-D. Ying, "Wind-resistant performance of cable-supported bridges using carbon fiber reinforced polymer cables," Wind and Structures, vol. 10, no. 2, pp. 121-133, 2007.

[17] C.-H. Kou, X. Xie, C.-S. Gao, and J.-Y. Huang, "Static behavior of long-span cable-stayed bridges using carbon fiber composite cable," Journal of Zhejiang University, vol. 39, no. 1, pp. 137-142, 2005.

[18] X. Xie, J. S. Gao, C. H. Kou, and J. Y. Huang, "Structural dynamic behavior of long-span cable-stayed bridges using carbon fiber composite cable," Journal of Zhejiang University (Engineering Science, vol. 39, no. 5, pp. 728-733, 2005.

[19] X. Xie, X. Li, and Y. Shen, "Static and dynamic characteristics of a long-span cable-stayed bridge with CFRP cables," Materials, vol. 7, no. 6, pp. 4854-4877, 2014.

[20] X. Wang, Z. Wu, G. Wu, H. Zhu, and F. Zen, "Enhancement of basalt FRP by hybridization for long-span cable-stayed bridge," Composites Part B: Engineering, vol. 44, no. 1, pp. 184-192, 2013.
[21] X. Wang and Z. Wu, "Evaluation of FRP and hybrid FRP cables for super long-span cable-stayed bridges," Composite Structures, vol. 92, no. 10, pp. 2582-2590, 2010.

[22] X. Wang and Z. Wu, "Integrated high-performance thousandmetre scale cable-stayed bridge with hybrid FRP cables," Composites Part B: Engineering, vol. 41, no. 2, pp. 166-175, 2010.

[23] Z. Fang, L. Ren, and F. Fan, "Behaviors of super-long span prestressed cable-stayed bridge with CFRP cables and UHPC girder," Engineering Sciences, vol. 14, no. 7, pp. 53-59, 2012.

[24] W. Xiong, C. S. Cai, R. Xiao, and L. Deng, "Concept and analysis of stay cables with a CFRP and steel composite section," KSCE Journal of Civil Engineering, vol. 16, no. 1, pp. 107-117, 2012.

[25] Z. S. Wu and X. Wang, "Investigation on a thousand-meter scale cable-stayed bridge with fiber composite cables," in Proceedings of the 4th International Conference on FRP Composites in Civil Engineering, Zurich, Switzerland, July 2008.

[26] W. Xiong, C. S. Cai, Y. Zhang, and R. Xiao, "Study of super long span cable-stayed bridges with CFRP components," Engineering Structures, vol. 33, no. 2, pp. 330-343, 2011.

[27] H. Li, Y. Huang, W. L. Chen, M. L. Ma, D. W. Tao, and J. P. Ou, "Estimation and warning of fatigue damage of FRP stay cables based on acoustic emission techniques and fractal theory," Computer-Aided Civil and Infrastructure Engineering, vol. 26, no. 7, pp. 500-512, 2011.

[28] B. H. Wang, Structure Develop of Cable-Stayed Bridge and Chinese Experience, China Communications Press, 2003. 


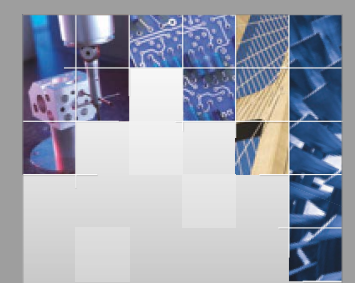

\section{Enfincering}
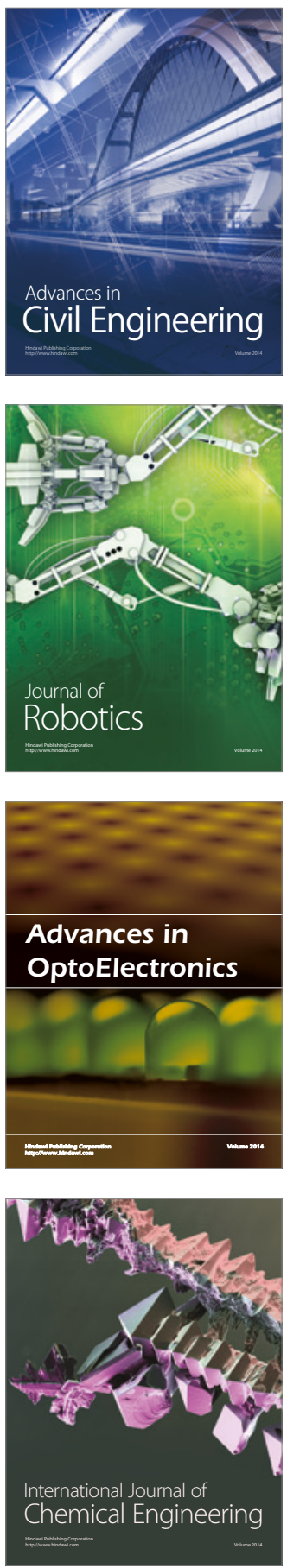

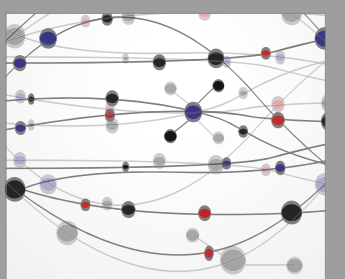

The Scientific World Journal

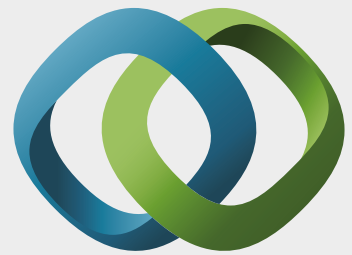

\section{Hindawi}

Submit your manuscripts at

https://www.hindawi.com
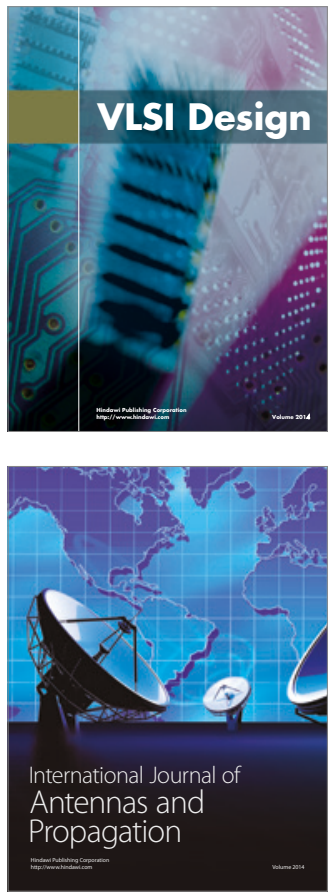

\section{Rotating}

Machinery
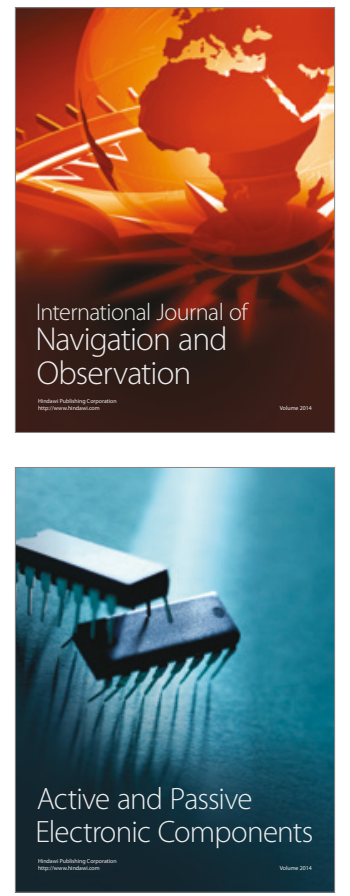
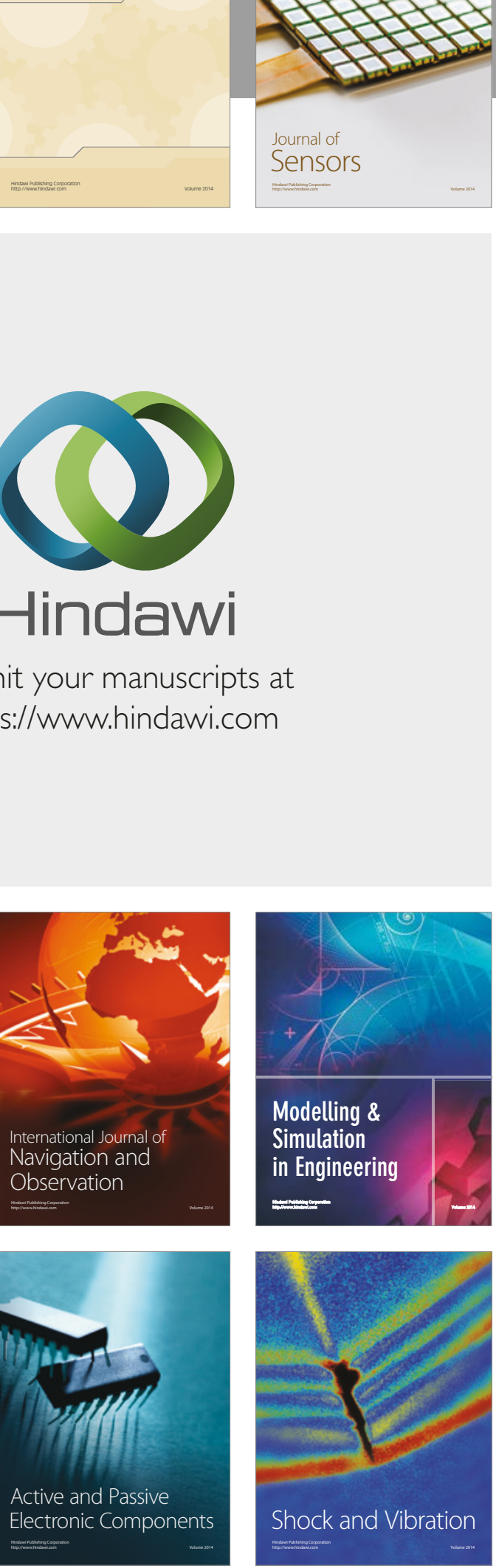
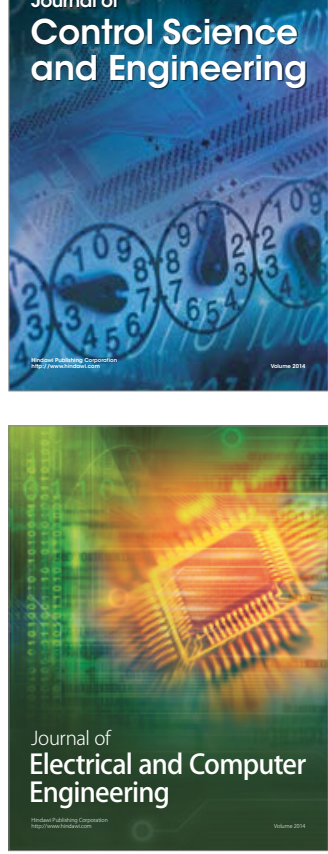

Distributed

Journal of

Control Science

and Engineering
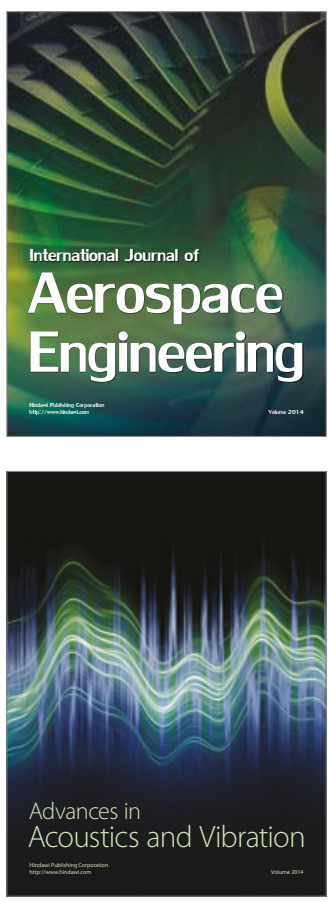

Sensor Networks 